\title{
JUSTYNA WOJCIECHOWSKA
}

Akademia Techniczno-Humanistyczna w Bielsku-Białej, Katedra Pedagogiki

\section{Dynamika analiz współczesnych dyskursów w świetle zmieniającej się kultury znaczeń}

\author{
Ze wszystkich ludzkich potrzeb jedynie „potrzeba rozumu” nie może \\ zostać zaspokojona bez myśli dyskursywnej; a dyskursywna myśl jest nie do pojęcia \\ bez słów mających znaczenie, zanim umysł zacznie wśród nich swą podróż.
}

Hannah Arendt, Myślenie

Współczesne dyskursy przyjmują różnorodne oblicza. Przestrzenie społecznego życia generują potrzebę istnienia rozmaitych form komunikacji. Dyskurs jako „rozmowa, dyskusja, przemowa” [Dunaj 2001: 215] z założenia powinien zapewniać porozumienie $\mathrm{w}$ znaczeniu rozumianym jako „komunikowanie się z kimś słownie bądź w inny sposób [...], dochodzenie z kimś do wspólnych poglądów, zgodę co do czegoś, uzgadnianie sprawy, dogadywanie się" [Dunaj 2001: 108], może również, ale nie musi oznaczać „wspólnotę poglądów w jakiejś sprawie, jednomyślność w danej kwestii, zgodę na coś” [Dunaj 2001: 108]. Człowiek, jako istota myśląca, wyróżnia się silną potrzebą komunikowania myśli. Myśli istnieją w naszym umyśle, mogą „zdarzać się”, powstawać bez werbalizacji słów, jednak w przestrzeni istnieją dzięki wypowiedzeniu. Wypowiedzenie to może być milczące ${ }^{1}$ lub może brzmieć w dialogu. Myślenie wydarza się w słowach, nie wymaga obecności słuchaczy, ale ponieważ istnienie człowieka ucieleśnia się pośród innych, siła potrzeby komunikacji jest niezwykła [Arendt 1991: 149]. Przyjmując założenie Ralfa Konersmanna, że istnienie świata jest uwarunkowane perspektywą kulturową, której istotą jest rozważanie faktów (ang. faits) jako faktów kulturowych (ang. faits culturels), zakładam, że dyskurs stanowi fundament

${ }^{1}$ Mam na uwadze mowę ciała człowieka, za pomocą której sugestywnie przekazuje on niewypowiedziane znaczenia słów; temat obszerny, nie stanowi przedmiotu moich dociekań w tym miejscu, analizowany m.in. przez: A. Donghi [1999], E. Goffman [2006], P. Holinger [2006], D. G. Leathers [2007], E. Goffman [2008] i in. 
tego procesu, tym bardziej, że jak twierdzi Konersmann za Emanuelem Kantem - „cały obszar kultury funkcjonuje według [...] modelu metafory” [Konersmann 2009: 6].

Celem tekstu jest wskazanie istoty dyskursu z odniesieniem do szczegółowych składników, które nadają mu ostateczny kształt i charakter. Relacje zachodzące pomiędzy znaczeniami pojęć budującymi tekst a ich funkcją poetycką, obrazującą, jak również kompetencje językowe, społeczne odbiorców odpowiadają za poziom uszczegółowienia odbioru, umiejętność odniesienia do kontekstów, rozumienia i interpretacji. Tekst ma na celu wskazanie na wielogłosowość stanowisk badaczy tekstu, co jest wykładnikiem dynamiki prowadzonych analiz z powodzeniem podążających za zmieniającą się kulturą znaczeń. Jednym z elementów dowodzących zmiany kultury znaczeń są zasady nowej tekstowości².

Analiza współczesnych dyskursów jest wyzwaniem nie tylko dla językoznawców. Własną przestrzeń badawczą z powodzeniem odnajdują w niej również pedagodzy, psychologowie, socjolingwiści, neurolingwiści. Wieloaspektowość prowadzonych analiz stwarza rozległe pole naukowe, z którego, w zależności od czynników determinujących ostateczny charakter, wyłaniają się spójne części, podzielne według przyjętych kryteriów. Każda kultura sama w sobie znaczy i oznacza. Semantyka pola kulturowego pozwala na wyłonienie czterech zastosowań znaczenia pojęcia. Dokonując rozważań na fundamencie twierdzeń Ralfa Konersmanna, przyjmuję, że humanizacja świata to proces, który trwa i który stawia wymagania cywilizacji i jej osiągnięciom. Konersmann zakłada, że deskryptywne pojęcie kultury odnosi się do świata tworzonego przez ludzi, do form wytworów będących wynikiem ich produkcji i reprodukcji pozostających $w$ granicach ich działania zgodnego z obyczajami, mentalnością i porządkiem symbolicznym. Pojęcie kultury uwzględniające charakterystyczną dwoistość rozwoju ma charakter dynamiczny. Płaszczyzna materialna łączy się z płaszczyzną refleksyjną, co umożliwia człowiekowi opisywanie siebie poprzez odwołanie do konwencji, wyobrażeń i podstawowych zasad funkcjonowania w społeczeństwie. Koncepcja archeologiczna wytycza warunki i konteksty, wskazuje na tradycję, odnosząc się jednocześnie do głębokich przekonań, refleksji, sentymentów, które pozwalają na przyjęcie określonego dystansu w interpretacji. Koncepcja normatywna umożliwia uchwycenie różnic dzięki procesowi rekonstrukcji, który pozwala jednocześnie na przyjęcie określonych hierarchii. Wyznaczenie koncepcji kultury czyni ją kluczową wśród uniwersalizmu i pozwala na odmienność wobec zastanych wzorców [Konersmann 2009: 13-14].

Myślenie jest uwarunkowane kulturowo. Nauka głoszona przez Sobór Watykański II głosi, że kultura to: ,,[...] wszystko, czy, człowiek doskonali i rozwija wielorakie uzdolnienia swego ducha i ciała; stara się drogą poznania i pracy poddać sam świat pod swoją władzę; czyni bardziej ludzkim życie społeczne tak

${ }^{2}$ Termin użyty przez J. Warchalę [2003]. 
w rodzinie, jak i w całej społeczności państwowej przez postęp obyczajów i instytucji; wreszcie w dziełach swoich w ciągu wieków wyraża, przekazuje i zachowuje wielkie doświadczenia duchowe i dążenia na to, aby służyły one postępowi wielu, a nawet całej ludzkości [Borutka 2005: 102]. Według Antoniny Kłoskowskiej „kultura stanowi wieloaspektową całość, w której drogą analizy wyróżnić można zinternalizowaną, tkwiącą w świadomości ludzi warstwę norm, wzorców i wartości, warstwę działań będących zobiektywizowanym wyrazem tamtej sfery, warstwę wytworów takich czynności lub innych obiektów stających się przedmiotem kulturowych działań" [Kłoskowska 1991: 23-24]. Zrozumienie człowieka wymaga odniesienia do kultury, w której funkcjonuje, do kultury, z której wyrasta jego tożsamość. Pojęcie kultury pochodzi od łac. cultura od colere, co oznacza uprawiać. To rozumienie znaczenia funkcjonuje współcześnie w określeniu typu pole o wysokiej kulturze, kultura bakterii, co oznacza przekształcenie naturalnego stanu zjawisk przyrody w stan bardziej użyteczny. Kultura w takim rozumieniu stanowi rezultat działań w przestrzeni zjawisk naturalnych przeciwstawiający się naturze, to ład, o którego porządku decyduje człowiek, zgodny z hierarchią ustalonych wzorów i norm. Kultura ma charakter społeczny, międzyindywidualna, stanowi wytwór zbiorowy i wspólny dla członków pozostających w obrębie określonych grup, kręgów, warstw [Kłoskowska 1991: 17-19]. Jest ściśle powiązana z tym, kim człowiek jest, natomiast to co ma stanowi związek wtórny, względny, ale to, co posiada ,[...] o tyle jest kulturotwórcze, o ile człowiek przez to, co posiada, może [...] pełniej być jako człowiek [...] we wszystkich właściwych dla człowieczeństwa wymiarach jego bytowania" [Jan Paweł II 1981: 21, por. Borutka 2005: 103]. Definicja kultury w świetle znaczenia opisanego w Słowniku wspótczesnego języka polskiego sprowadza się do rozumienia pojęcia jako „ogół duchowego i materialnego dorobku ludzkości wytworzony na kolejnych etapach rozwoju historycznego, nieustannie utrwalany i wzbogacany [...], pewien poziom umiejętności, stopień doskonałości, sprawności w opanowaniu jakiejś specjalności, pewien poziom rozwoju, zwłaszcza intelektualnego" [Dunaj 2001: 442].

Współczesna kultura i jej dyskursy, będące wykładnikiem owego poziomu rozwoju intelektualnego, ulegają dynamicznym przemianom, co wiąże się również z kształtem językowego obrazu świata [Bartmiński 2004: 7, Grzegorczykowa 2004: 39]. Język stanowi nasze wyposażenie światopoglądowe, językowy obraz świata przejmujemy z akwizycją języka. Podstawowy zestaw form i zwrotów językowych wyznacza, ale jednocześnie ogranicza nasze widzenie rzeczywistości. Tworzony przez nas obraz świata zależy od struktury języka, w którym dany obraz jest tworzony. Nasze myśli zawsze mogą przybrać kształt werbalny w konkretnym języku [Schaff 1981: 6, por. Warchala 2003: 30], ujednolicając tym samym wielosystemowość kultur. Zakładając, że kultura może trwać dzięki przekazowi i porozumieniu, sprowadzamy jej żywotność do znaczenia ujętego w myślach, ucieleśnionych w słowach, zapisanych w znakach, objawionych w symbolach i zwerbalizowanych w języku. Słowo i język stają się nośnikami 
istnienia. Określone zasady decydują o nominacji wytworu do określonej przestrzeni, która z założenia ma trwać, dlatego kultura może być rozumiana jako niekończący się zbiór tekstów, odpowiadających tylko i wyłącznie właściwym zasadom tekstowości.

Semiotyzacja i desemiotyzacja [Dmitruk 1989: 23] powodują, że określone przekazy stają się tekstami³ , a inne do nich nie należą. Określając zasady nowej tekstowości ${ }^{4}$, która jest jednym z elementów dowodzących zmiany kultury znaczeń, Jacek Warchala i Aldona Skudrzyk jako cechę ważną wyłaniają autonomiczność i spójność. Pytanie postawione w celu ustalenia istoty tekstu spójnego w ujęciu współczesnym w rozważaniach Warchali i Skudrzyk rodzi odpowiedź, że $\mathrm{w}$ rozumieniu tradycyjnym tekst jest przede wszystkim jedynie pretekstem, dostarcza znaczeń, a ustalenie sensów jest rolą czytelnika, odbiorcy. Sam złożony proces czytania stanowi wyzwanie dla konstruowania indywidualnych, spójnych rozumień. Umożliwienie poznania, poddanie aktualizacji i negocjacji stanowią fundament kognitywnego doświadczenia. O spójności decyduje sytuacyjność, wizualność i interakcyjność, przy czym Warchala i Skudrzyk wprowadzają kategorie pomocnicze, takie jak: opozycja parataktyczność $v s$. hipotaktyczność ${ }^{\mathrm{i}}$ linia vs. pole tematyczne ${ }^{6}$ [Warchala, Skudrzyk 2010: 151-155].

Intensywny rozwój cywilizacji powoduje, że znaczenia współczesnej kultury ulegają zmianom. W świetle zagadnienia dotyczącego społecznych funkcji edu$k_{a c j i}{ }^{7}$ [Hinc 2010] istota analiz narracji nabiera szczególnego znaczenia - staje się nośnikiem wiedzy o człowieku i charakterze jego doświadczeń. Dyskurs pedagogiczny, jako dyskurs kształtujący osobowość i wnętrze młodego pokolenia, ze wszech miar wymaga spójności i przejrzystości, ponieważ warunkiem „[...] wytwarzania, odtwarzania i przekształcania kultury" jest wewnętrzne uporządkowanie instrumentu pedagogicznego, który dzięki regułom dystrybucyjnym,

${ }^{3}$ O tekście i zasadach tekstowości na gruncie polskim pisali m.in.: T. Dobrzyńska [1990], J. Warchala [1991], D. Ostaszewska [1991], T. Dobrzyńska [1993], B. Witosz [1997], K. Michalewski (red.), [2000], D. Ostaszewska (red.), [2004].

${ }^{4}$ Termin użyty przez J. Warchalę [2003].

${ }^{5}$ Zasada spójności współczesnego tekstu zostaje przez Warchalę i Skudrzyk ujęta jako opozycja kolekcji i relacji rozumiana jako zasada budowy tekstu w części lub w całości oraz jako reguła konceptualizacji świata, w której dzięki odniesieniom parataktycznym blokowane jest myślenie abstrakcyjne na rzecz konkretnego, parataksa skanuje, prześwietla zdarzenia, hipotaksa pozwala interpretować [por. Warchala, Skudrzyk 2010: 151].

${ }^{6}$ Spójność tekstu jest uwarunkowana tematem, w rozmowie potocznej spójność często wynika $\mathrm{z}$ dialektyki pola i linii tematycznej. Istnienie pola może być uwarunkowane zasadą, która dezintegruje tematyczną jedność, linia będzie wytyczała kierunek rozwoju mowy. Pole tematyczne to wszelkiego rodzaju konotacje pozostające w związku z tematem głównym, tworzącym na bazie skojarzeń wspólną przestrzeń, natomiast linia tematyczna stanowi logiczną sekwencję wypowiedzeń [Warchala, Skudrzyk 2010: 154].

7 Zagadnieniu temu poświęcił uwagę S. Hinc [2010].

8 Sformułowanie zaczerpnięte dokładnie z publikacji B. Bernsteina [1990]. 
rekontekstualizacyjnym i oceniania zaopatruje język w środki niezbędne do konstruowania dyskursu pedagogicznego [Bernstein 1990: 167]. W minionych latach socjologia edukacji często pomijała analizę cech wewnętrznych, które stanowiły o specyfice pedagogicznego dyskursu procesu kształcenia [Bernstein 1990: 163]. Pomimo doświadczeń i refleksji małą uwagę przywiązywano do zagadnienia praktyk regulacyjnych w analizie dyskursu pedagogicznego. Socjologia edukacji $\mathrm{w}$ nowym wymiarze $\mathrm{w}$ latach siedemdziesiątych minionego stulecia poddawała analizie wiedzę i sposoby jej przyswajania, formuły przekazywania i ocenianie w szkole. Największe zasługi na polu odtwarzania stosunków klasowych w odniesieniu do edukacji Basil Bernstein przypisywał Bordieu i Passeronowi, którzy zajęli się m.in. zasadami komunikacji, jak również systemem znaczeń przekazywanych w tym procesie. Próbując uogólnić specyficzny dyskurs edukacyjny, rozróżnili oni dwie formy komunikowania: mentorską i potoczną. Mentorska forma charakteryzowała osoby, których zadaniem było przekazywanie wiedzy, natomiast potoczna została przypisana klasie robotniczej. Bourdieu i Passeron w szczególności zajęli się stosunkiem do komunikowania pedagogicznego niż samą analizą stosunków w obrębie procesu o określonej formie [Bernstein 1990: 165-166].

Przełomowe okazały się badania Delamonta, Stubbsa, Hymesa, Edwardsa, w których autorzy z góry zakładali analizę zasad komunikowania i praktyki interakcyjnej w odniesieniu do klasy warunków determinujących społeczność klasy szkolnej. Znacznie mniejszą uwagę poświęcono zagadnieniu sprowadzającemu się do założenia, że reguły dyskursu ustanawia dystrybucja władzy. Dyskurs pedagogiczny jako zbiór reguł warunkujących specjalistyczne formy komunikowania jest uwarunkowany regułami rekontekstualizacyjnymi. W rozumieniu Bernsteina posiada on moc różnicowania transmisji i przyswajania, przy czym właściwością charakterystyczną jest uprzywilejowanie do osadzenia dyskursu dotyczącego kompetencji w dyskursie społecznego ładu w układzie, w którym ład społeczny dominuje nad kompetencjami. Dzięki zasadzie rekontekstualizacji jest możliwa reorientacja innych form dyskursu na potrzebę i użytek specyfiki dyskursu pedagogicznego na podstawie przejmowania innych kodów i połączeń pomiędzy nimi [Bernstein 1990: 171-172].

Dyskurs pedagogiczny jest spójny z nauką o społeczeństwie, która jest nauką młodą , tym bardziej wymaga wielości analiz w różnych aspektach, odnoszących się do poszczególnych jej przestrzeni. Sławomir Hinc, omawiając znaczenie teorii reprodukcji, przyjmuje, za Bourdieu, że język jest najwłaściwszym narzędziem dla edukacji, przy czym dla analiz istotny jest przyswojony i używany zakres słów. Wypracowana w trakcie złożonego procesu socjalizacji medialna mentalność, jak pisze Autor, osadzona w środowisku użytkownika, pozwala jednostce na ukazanie osobowości na zewnątrz [Hinc 2010: 175]. Język, mowa i wiedza są fundamentami dla spójnego dyskursu, który przed kompetentnym użytkownikiem

9 Myśl ta rozpoczyna wprowadzenie w treść monografii S. Hinca [2010]. 
języka otwiera właściwe jemu przestrzenie, warunkuje samorealizację, ucieleśnia dążenia, dając podstawy pewności i poczucia wartości własnej osoby. Zadaniem pedagogicznego dyskursu w całym procesie edukacji jest wykazanie szczególnej dbałości o poziom kompetencji językowych jednostek, który w dużej mierze warunkuje istnienie człowieka w świecie, umożliwiając rozumienie, tworzenie i przetwarzanie kultury. Socjolingwistyczne analizy procesu edukacji i jego kontekstów, uwzględniając dynamiczne zmiany współczesnej kultury, w której funkcjonuje człowiek, poszukują narzędzi do interdyscyplinarnych rozważań ${ }^{10}$.

Zarówno w dyskursie pedagogicznym, jak i innych metafora, wszechobecna w słowach mówionych i pisanych, w dużej mierze determinuje charakter przekazu, przez co bezpośrednio wiąże się ze stopniem rozumienia tekstu przez odbiorcę/odbiorców. Metafory, jako podstawowe formy użycia języka, warunkują jego obrazowość. Metafora pełni funkcję wyjaśniającą, ewentualnie ułatwia zrozumienie: „istotą metafory jest rozumienie i doświadczanie pewnego rodzaju rzeczy $\mathrm{w}$ terminach innej rzeczy [...], a podstawową funkcją metafory jest zapewnienie częściowego zrozumienia pewnego doświadczenia w terminach innego doświadczenia" [Lakoff, Johnson 1988: 27, por. Jäkel 2003: 33]. Metafora jest więc podstawowym mechanizmem, dzięki któremu rozumiemy abstrakcyjne pojęcia oraz dokonujemy abstrakcyjnego rozumowania. Większość treści, od najbardziej przyziemnych po najbardziej zawiłe teorie naukowe, można zrozumieć poprzez metaforę [Lakoff 1993a: 244, por. Jäkel 2003: 34].

Metaforyczność przekazu buduje kulturę, której odbiór jest uwarunkowany możliwością porozumiewania się umysłów [Frith 2013: 171]. Badanie relacji umysł - język jest fundamentem kognitywizmu - nauki, zadaniem której jest przedstawienie propozycji analizy strukturalnej i jasnego opisu abstrakcyjnych bytów, jakimi są myśli i pojęcia. Pojęcie konceptualizacji jest rozumiane szeroko: zawiera nowe i jednocześnie utrwalone pojęcia, doświadczenia zmysłowe: kinestetyczne i emotywne, identyfikację bezpośredniego kontekstu społecznego, fizycznego i językowego. Konceptualizacja stanowi integralną część procesów kognitywnych, dlatego celem analizy jest dążenie do charakterystyki typów wydarzeń kognitywnych, które budują doświadczenia mentalne człowieka [Langacker 1991a: 2]. Gramatyka kognitywna przyjmuje podstawowe założenie, że fundamentalne i uniwersalne konstrukty - pojęcia takie jak rzeczownik, czasownik, podmiot, dopełnienie - można scharakteryzować konceptualnie [Langacker 2006: 19] w dyskursie. Znaczenie pojęcia rozumiane jest jako konceptualizacja przedmiotu w poznaniu. Wykorzystując dane językowe zawarte w kontekście, można odtworzyć symboliczne rozumienie przedmiotu, które składa się na pojęcie. Podawanie znaczenia jest (re) k o n s t r u o w a n i e m na podstawie//z empirii

10 Jednym z wielu wykładników rozważań na temat metodologii badań jakościowych jest praca zbiorowa pod redakcją N. K. Denzin, Y. S. Lincoln [2009]. 
językowej [Langacker 2006: 19]. Pojedyncza metafora pojęciowa jest podstawą wielu konceptualizacji abstrakcyjnej domeny pojęciowej. Wyobraźnia uruchamia kreatywność, a metafora pozwala przekształcać ludzkie doświadczenia. Kognitywna teoria metafory musi brać pod uwagę uprzedzenia i nieporozumienia zrodzone w ciągu dwóch tysięcy lat tradycji. Impresjonistyczne traktowanie metafory kształtuje jej rozumienie jako ,językowego wyrazu twórczości poetyckiej oraz poszukującej efektu retoryki" [Jäkel 2003: 20]. Metafora językowa nie jest charakterystyczna wyłącznie dla poetyckiego dyskursu. Metafory są wszechobecne, natomiast „,w dostrzeżeniu tego powszechnego zjawiska prawdopodobnie przeszkadza jego pospolitość oraz towarzyszący mu efekt przyzwyczajenia" [Jäkel 2003: 20]. Posługiwanie się, rozumienie i umiejętność stworzenia metafory powinny stanowić zasadniczy element kompetencji językowej, ponieważ metafory są zakorzenione w systemie pojęciowym człowieka. Doniosłość znaczeniowa istnienia metafory w kulturze tkwi w tym, że występuje ona tam, gdzie wskazuje na coś, co znajduje się poza jej zasięgiem i wskazuje na to, czym sama nie jest. Konersmann podkreśla, że metafora zachowuje sens i można ją praktycznie stosować tam, gdzie ktoś ma COŚ na myśli. Jednocześnie sama logika metaforyczności odpowiada za określenie przejawów kultury, determinując tym samym je jako coś, co nigdy nie pokrywa się z tym, co przejawia [Konersmann 2009: 7-9].

Dowodem dynamiki analiz współczesnych dyskursów w świetle zmieniającej się kultury znaczeń jest krytyczne podejście do analizy dyskursu, które pozwoliło na połączenie/zbliżenie dotychczas przeprowadzonych badań [Fairclough, Duszak 2008: 9] (w tym abstrakcyjnych domen dyskursów [por. Jäkel 2003]), w których metafora zajmuje integralną podstawę badań. Problemy współczesnego świata stanowiące odwzorowanie przekształcającej się kultury stanowią oś zainteresowań badaczy skupionych wokół KAD. Krytyczna analiza dyskursu jest nową przestrzenią badawczą stworzoną dla lingwistyki i nauk społecznych. Traktowana jako pojedynczy obszar badawczy prezentuje różnorodność stanowisk osób współtworzących. KAD scala stanowiska odnoszące się do zależności zachodzących pomiędzy językiem/dyskursem a współtowarzyszącymi elementami procesów społecznych, które jako konstruowane w warunkach naturalnych stanowią oś znaczenia. Krytyczna analiza dyskursu kieruje uwagę na związki przyczynowo-skutkowe, interpretację, objaśnienia, kulturę i materialność, subiektywizm, obiektywizm, działania i struktury. Przyjęcie definicji dyskursu jako semiozy rozumianej w kategorii wytwarzania znaczeń za pomocą całego wachlarza środków semiotycznych o charakterze werbalnym i niewerbalnym pozwala na przeprowadzenie szczegółowej analizy relacji zachodzących pomiędzy dyskursem a elementami niedyskursywnymi, co generuje potrzebę odwołania do charakteru zjawisk konstruowanych społecznie. Dzięki takim założeniom krytyczna analiza dyskursu jest podejściem zorientowanym na dialog pomiędzy dyscyplinami i nawiązywanie relacji z przestrzeniami nauk społecznych. 
Podsumowując, KAD przedmiotem badań czyni procesy i problemy społeczne, zakładając, że dyskurs jako ważny element relacji władzy stanowi kluczowy czynnik w społecznej konstrukcji społecznego życia, odnosi się do szczegółowej analizy tekstu [Fairclough, Duszak 2008: 8-15]. Mając na uwadze powyższe, można jednoznacznie stwierdzić, że krytyczna analiza dyskursu, charakteryzująca się dynamiką istnienia przejawianą w wyszczególnianych elementach analiz, stanowi doskonałe narzędzie dla pełnego rozumienia współczesnych dyskursów w świetle zmieniającej się kultury znaczeń.

Zmieniająca się rzeczywistość, a wraz z nią kultura znaczeń, wymaga od badaczy współczesnych dyskursów dynamicznej postawy, umożliwiającej analizy. Zasady nowej tekstowości, wyznaczone przez autonomiczność i spójność, wieloaspektowa analiza wszechobecnych metafor obrazują kształt współczesnego językowego obrazu świata. Przedmioty badawcze ustalone do analizy wymagają zastosowania właściwej metodologii w celu wydobycia wiedzy związanej z określonym wycinkiem przestrzeni. Zagadnienia związane ze współczesnym funkcjonowaniem człowieka w świecie wymagają dynamicznego spojrzenia, ponieważ wielość i różnorodność ich charakteru stawiają przed badaczem niełatwe wyzwanie próby wniknięcia w umysł, który dyskurs stworzył.

\section{Bibliografia}

Arendt H. [1991], Myślenie, Czytelnik, Warszawa.

Bartmiński J. [2004], Językowy obraz świata, Wydawnictwo UMCS, Lublin.

Bernstein B. [1990], Odtwarzanie kultury, Państwowy Instytut Wydawniczy, Warszawa.

Borutka T. [2005], Jan Paweł II wobec modelu kultury wspótczesnej Europy (Na marginesie adhortacji apostolskiej Jana Pawła II Ecclesia in Europa, [w:] A. Będkowska-Kopczyk (red.), Świat i słowo, Wydawnictwo Instytutu Teologicznego, Bielsko-Biała.

Denzin N. K., Lincoln Y. S. (red.) [2009], Metody badań jakościowych, Tom I, II, Wydawnictwo Naukowe PWN, Warszawa.

Dmitruk K. [1989], Galaktyki kultury, [w:] H. Dziechcińska (red.), Kultura żywego słowa w dawnej Polsce, PWN, Warszawa.

Dobrzyńska T. [1990], Tekst w kontekście: zbiór studiów, Polska Akademia Nauk, Instytut Badań Literackich, Zakład Narodowy im. Ossolińskich, Wrocław.

Dobrzyńska T. [1993], Tekst: próba syntezy, Polska Akademia Nauk, Instytut Badań Literackich, Warszawa.

Donghi A. [1999], Gesty i stowa: wprowadzenie do języka symbolicznego, Wydawnictwo WAM, Kraków.

Dunaj B. [2001], Stownik współczesnego języka polskiego, Reader's Digest Przegląd, Warszawa.

Fairclough N., Duszak A. [2008], Krytyczna analiza dyskursu. Interdyscyplinarne podejście do komunikacji społecznej, Towarzystwo Autorów i Prac Naukowych „Universitas”, Kraków.

Frith Ch., [2013], Od mózgu do umystu. Jak powstaje nasz wewnętrzny świat, Wydawnictwo Uniwersytetu Warszawskiego, Warszawa.

Goffman E. [2006], Rytuat interakcyjny, Wydawnictwo Naukowe PWN, Warszawa.

Goffman E. [2008], Zachowanie w miejscach publicznych, Wydawnictwo Naukowe PWN, Warszawa. 
Grzegorczykowa R. [2004], Pojęcie językowego obrazu świata, [w:] J. Bartmiński (red.), Językowy obraz świata, Wydawnictwo UMCS, Lublin.

Hinc S. [2010], Spór o społeczne funkcje edukacji. Z perspektywy teorii funkcjonalizmu strukturalnego i teorii konfliktu, Wyższa Szkoła Zawodowa „Kadry dla Europy”, Poznań.

Holinger P. [2006], Co mówia dzieci, zanim naucza się mówić: dziewięć sygnałów używanych przez dzieci do wyrażania uczuć, Media Rodzina, Poznań.

Kłoskowska A. [1991], Encyklopedia Kultury Polskiej XX wieku. T. 1, Pojęcia i problemy wiedzy o kulturze, Wiedza o Kulturze, Wrocław.

Konersmann R. [2009], Filozofia kultury, Oficyna Naukowa, Warszawa.

Langacker R. W. [2006], Gramatyka konstrukcyjna, konstrukcje gramatyczne i gramatykalizacja, [w:] O. Sokołowska (red.), Językoznawstwo kognitywne III. Kognitywizm w świetle innych teorii, D. Stanulewicz, Gdańsk.

Leathers D. G. [2007], Komunikacja niewerbalna: zasady i zastosowania, przekł. M. Trzcińska, red. nauk. Z. Nęcki, Wydawnictwo Naukowe PWN, Warszawa.

Michalewski K. (red.) [2000], Regulacyjna funkcja tekstów, Wydawnictwo Uniwersytetu Łódzkiego, Łódź.

Ostaszewska D. [1991], Organizacja tekstu a problem gromadzenia i scalania jego informacji, Wydawnictwo Uniwersytetu Śląskiego, Katowice.

Ostaszewska D. (red.) [2004], Tekst a gatunek, Wydawnictwo Uniwersytetu Śląskiego, Katowice.

Warchala J. [1991], Dialog potoczny a tekst, Wydawnictwo Uniwersytetu Śląskiego, Katowice.

Warchala J. [2003], Kategoria potoczności w języku, Wydawnictwo Uniwersytetu Śląskiego, Katowice.

Warchala J., Skudrzyk A. [2010], Kultura piśmienności młodego pokolenia, Wydawnictwo Uniwersytetu Śląskiego, Katowice.

Witosz B. [1997], Opis w prozie narracyjnej na tle innych odmian deskrypcji: zagadnienia struktury tekstu, Wydawnictwo Uniwersytetu Śląskiego, Katowice. 